\title{
Retrospective evaluation of our percutaneous biopsy results of renal masses
}

\author{
Renal kitle perkütan biyopsi sonuçlarımızın retrospektif incelenmesi \\ Ilyas Dundar ', Fatma Durmaz', Sercan Ozkacmaz ', Nazim Abdulkadir Kankilic ${ }^{2}$, Abdullah Gul $^{3}$, Mesut Ozgokce ${ }^{1}$ \\ 1 Van Yüzüncü Yıl University, Faculty of Medicine, Department of Radiology, Van, Turkey \\ 2 University of Health Science, Van Training and Research Hospital, Department of Urology, Van, Turkey \\ 3 University of Health Science, Bursa Yüksek Intisas Training and Research Hospital, Department of Urology, Bursa, Turkey
}

Submitted: 2020-10-31

Accepted: 2021-01-23

\author{
Correspondence \\ İlyas Dündar \\ Van Yüzüncü Yıl Üniversitesi \\ Dursun Odabaşı Tip Merkezi \\ Radyoloji A.D. 65080, Kampüs, \\ Tuşba, Van / Turkey \\ e-mail: dundarilyas262@hotmail.com \\ T: +90 4322150470 \\ F: +904322168519
}

\section{ORCID}

I.D. 0000-0002-1429-077X

F.D. $\quad 0000-0003-3089-7165$

S.O. 0000-0002-9245-0206

N.A.K. $\quad 0000-0002-3747-3798$

A.G. $\quad 0000-0001-7117-9210$

M.O. 0000-0002-3095-2446

\section{cC) (9)}

This work is licensed under a Creative Commons Attribution-NonCommercial 4.0 International License.
Özet

Amaç: Bu çalışmada kliniğimizde solid böbrek lezyonlarına yapılan perkütan biyopsilerinin retrospektif sonuçlarını literatür eşliğinde sunmayı amaçliyoruz.

Gereç ve Yöntemler: Kendi merkezimizde etik kurulunca onaylanan bu retrospektif tanımlayıcı çalışmada 2017-2020 yılları arasında böbrekte solid kitle tespit edilen ve girişimsel radyoloji kliniğimizde ultrasonografi eşliğinde perkütan böbrek biyopsisi yaptığımız 57 hastanın demografik özellikleri ve histopatolojik sonuçları hastane veri tabanından taranarak elde edilen sonuçlar incelendi. Patoloji sonucu olmayan hastalar çalışma dıșı bırakıldı.

Bulgular: Hastalarımız 35 erkek $(\% 61,4)$ ve 22 kadından $(\% 38,6)$ oluşmaktaydı. Yaş ortalaması 59,02 $\pm 15,33$ (6-94) idi. 1 çocuk ve 56 erişkin hastamız mevcuttu. Böbrek lezyonlarının 29'u sol böbrek (\%50,9), 28 'i sağ böbrek $(\% 49,1)$ yerleșimli idi. Patoloji sonuçları malign olan toplam 44 hastada (\%77,2); 41 renal hücreli karsinom $(\% 93,2)$, 2 akciğer skuamöz hücreli karsinom metastazı $(\% 4,5)$ ve 1 primeri bilinen tükrük bezinin metastaz yapan pleomorfik adenomu $(\% 2,3)$ ve sonucu benign olan toplam 13 hastada $(\% 22,8)$ ise; 5 onkositom (\%38,5), 5 anjiomyolipom (\%38,5), 2 kronik piyelonefrit $(\% 15,4)$ ve 1 metanefrik adenom $(\% 7,6)$ olarak elde edildi. Tüm lezyonlar içerisinde renal hücreli karsinom oranı \%71,9 olarak bulundu.

Sonuç: Tibbi görüntülemedeki son gelişmelere rağmen solid renal kitlelerin ayırıcı tanısında radyolojik yöntemler yeterli tanısal veri sağlamayabilir. Perkütan biyosi sonucunda literatüre kıyasla benign lezyon oranlarının çalışmamızda yüksek olması solid lezyonlarda cerrahi öncesi

\section{Abstract}

Objective: In this study, we aim to present the retrospective results of percutaneous biopsies performed on solid kidney lesions in our clinic with the literature.

Materials and Methods: In this retrospective descriptive study approved by the ethics committee in our center, the demographic features and histopathological results of 57 patients who had a solid mass in the kidney between 2017-2020 and underwent ultrasonography-guided percutaneous kidney biopsy in our interventional radiology clinic were analyzed from the hospital database. Patients without pathology results were excluded from the study.

Results: Our patients consisted of 35 men $(61,4 \%)$ and 23 women $(38,6 \%)$. The average age was $59.02 \pm 15.33$ (6-94). We had 1 child and 56 adult patients. 29 of the kidney lesions were located in the left kidney(50,9\%) and 28 were located in the right kidney(49,1\%). In 44 patients(77.2\%) who had malignant pathology; the results were 41 renal cell carcinoma(93.2\%), 2 lung squamous cell carcinoma metastasis(4.5\%) and 1 primary metastatic pleomorphic adenoma of the salivary gland(2.3\%). In a total of 13 patients(22.8\%) whose pathology results were benign; the results were 5 oncocytomas(38.5\%), 5 angiomyolipo$\mathrm{ma}(38.5 \%), 2$ chronic pyelonephritis(15.4\%) and 1 metanephric adenoma(7.6\%). Renal cell carcinoma rate was $71.9 \%$ among all lesions.

Conclusion: Radiological methods may not provide sufficient diagnostic data in the differential diagnosis of solid renal masses.In our study, the rates of benign lesions as a result of percutaneous biopsy were higher compared to the literature. 
biyopsinin önemi açısından dikkat çekici olduğunu düşünüyoruz. Ülkemizde geleceğe dönük doğru yaklaşım geliştirebilmemize yardımcı olabilecek çok merkezli ve prospektif çalışmalara ihtiyaç olacağı kanaatindeyiz.

Anahtar Kelimeler: renal kitle, perkütan biyopsi, renal hücreli karsinom
Therefore, we believe that it is remarkable in terms of the importance of preoperative biopsy in solid lesions.

Keywords: renal mass, percutaneous biopsy, renal cell carcinoma

\section{Giriş}

Renal kitleler, sıklıkla insidental olarak görülen geniş heterojen bir antitedir. Renal kitlelerin çoğunluğunu oluşturan renal kanserler, ürologenital kanserler arasında üçüncü sırada olup, erişkin tümörlerinin yaklaşık \%2-3'ünü oluşturur $(1,2)$. Böbrekten kaynaklanan malign kitlelerin \%90-95’i renal hücreli karsinom (RHK)'dur. RHK insidansı dünya genelinde 2018 yılında $\% 2,2$ ve mortalitesi $\% 1,8$ olarak saptanmıştır (2).

Renal kitleler genellikle abdominal yakınmalar sebebiyle yapılan radyolojik tetkikler sonrasinda insidental olarak ortaya çıkar (3). Ağrl, makroskopik hematüri ve abdominal kitle triadı hastaların sadece \%6-10'unda mevcuttur ve progresif hastalık ile ilişkilidir (4). Artan tanı oranları ile birlikte, RHK'dan ölüm oranları son yıllarda biraz azalmıştır (5). Ultrasonografi (USG), bilgisayarlı tomografi (BT) ve manyetik rezonans görüntüleme (MRG) gibi görüntüleme yöntemlerinin yaygınlaşması ile birlikte, insidental böbrek kitlelerinin daha küçük boyutlarda ve erken evrelerde teşhis edilebilmesi mümkün hale gelmiştir $(6,7)$. Renal kitlelerin tedavisi için kullanılan cerrahi ve ablatif tedavilerin kullanımının artması da renal kitlelerin daha sık ve erken evrelerde tedavi edilebildiğini göstermektedir (8). Erken teşhis ve yeni gelişen tedaviler ile birlikte beş yıllık sağkalım oranları 1975'te \%52,3 iken 2012'de \%76,8'e çıkmış ve sürekli artmaktadır. Amerikan ulusal kanser enstitüsünün SEER (The Surveillance, Epidemiology, and End Results) veritabanına göre 2010-2016 yılları arasında ortalama 5 yıllık sağkalım $\% 75,2$ olarak hesaplanmıştır. 5 yıllık sağkalım oranları lokalize böbrek kanserinde \%92,6, bölgesel yayılımı olanlarda $\% 70,4$ ve uzak metastazı olanlarda ise \%13'tür (9).

Sporadik tek taraflı metastatik olmayan renal kitle nedeniyle radikal veya parsiyel nefrektomi geçiren büyük bir cerrahi hasta serisinde, küçük renal kitlelerin önemli bir azınlığının $\left(<1 \mathrm{~cm}\right.$ 'lik kitlelerin $\left.>\% 45^{\prime} \mathrm{i}\right)$ histolojik olarak iyi huylu olduğu kanıtlanmıştır (10). Solid böbrek kitlelerinin tespiti ve benign-malign ay1rımı için öncelikle radyolojik görüntüleme yöntemleri kullanılmaktadır. Görüntüleme yöntemlerinin araşt1rıldığı bir çalışmada kontrastlı BT ve MRG’nin tanısal doğruluk oranları sırasıyla $\% 79,4$ ve $\% 88,2$ olmasina rağmen spesifiteleri düşük (sirasıly \%44,4 ve \%33,3) bulunmuştur (11). Tüm teknolojik gelişmelere rağmen radyolojik yöntemler renal kitlelerin ayırıcı tanısında halen yetersiz kalabilmektedir. Özellikle yağ dokusundan fakir anjiyomiyolipom (AML) ve onkositom gibi olguların radyolojik yöntemlerle malign neoplazmlardan ayırımında tanısal zorluklar bulunmaktadır $(12,13)$. Hasta sayısı fazla olan 3. basamak sağlık kuruluşunda çalışan hekimler için bu vakaların ayırımı önem taşımaktadır. Benign renal kitlelerin RHK'lar ile karışabilmesine ek olarak, histopatolojik tanı konan tüm RHK'lar aynı davranışı sergilemezler. RHK, çeşitli histolojik alt tipleri ve nükleer dereceleri olan heterojen bir hastalıktır ve bazıları daha agresif seyirlidir $(10,14)$. Berrak hücreli RHK'nin histopatolojik tümör derecesi, en önemli prognostik faktörlerden biri olarak kabul edilmektedir (15).

Perküktan renal biyopsi, renal kitlelerin benign-malign ayırımı için cerrahi yöntemlere kıyasla daha az invaziv bir yöntemdir ve malignite riskini derecelendirme potansiyeline sahip olması nedeniyle tedavi kararlarından önce gereksiz cerrahi veya ablatif tedavilerden kaçınmaya ve hasta riskinin daha iyi sınıflandırılmasına olanak sağlar (16). Düşünülenin aksine perkütan renal kitle biyopsisi, düşük komplikasyon oranı (<\%5), yüksek tanısal verim ( $\geq \% 94)$ ve patolojik tanıdaki doğruluğu da göz önüne alındığında artık güvenli ve etkili bir şekilde özellikle küçük renal kitlelerin yönetiminde daha büyük bir rol oynamaktadır (17-19).

$\mathrm{Bu}$ çalışmada kliniğimizde radyolojik görüntülemeler ile böbrekte solid kitle tespit edilen özellikle ma- 
lignite potansiyeli net ortaya konamayan ve perkütan renal biyopsi yapılan hastaların klinik, demografik ve histopatolojik verilerinin retrospektif sonuçlarını literatür eşliğinde sunmayı amaçladık.

\section{GEREÇ VE YÖNTEMLER}

\section{Hasta Seçimi}

2017-2020 yılları arasında, merkezimizde etik kurulunca onaylanan (2019/02) bu çalışmamızda; böbrekte solid komponenti ağırlıklı olan kitle tespit edilen ve perkütan böbrek biyopsisi yaptığımız 57 hastanın retrospektif sonuçları sunulmaktadır.

Biyopsi yapılmadan önce tüm hastalara merkezimizde ve dış merkezlerde USG ve/veya BT ve/veya MRG ile radyolojik görüntülemeler mevcuttu. Hastaların görüntülemeleri hastane veritabanından retrospektif olarak incelendiğinde bazı hastaların sadece BT tetkiki; bazılarının sadece MRG görüntüleri ve bazılarının ise hem BT hem de MRG görüntülemeleri bulunmaktaydı. BT'de lezyonlar kontrast tutan yumuşak doku dansitesinde izo-hiperdens özellikte idi. MRG'de T1 ve T2 ağırlıklı görüntülerde değişken sinyal intensitesinde kontrastlı görüntülerde kontrast tutan bazıla$\mathrm{r} 1$ ise heterojen solid lezyonlardı. Ancak görüntüleme yöntemleri klinik tedavi için yeterli kesin bir tanı sağlayamad. Girişimsel radyoloji ünitesine biyopsi için yönlendirilen tüm hastalara nihai olarak USG inceleme yapıldı. USG'de tüm lezyonlar izo-hipoekoik görünümde, doppler incelemede vaskülaritesi kodlanan solid lezyonlardi.

Merkezimizde, görüntüleme yöntemleri ile malignite potansiyeli tanımlanamamış kitleler; böbrek yetmezliği veya soliter böbreği olan hastalarda veya yaşlı hastalarda tespit edilen ve tedavi seçenekleri belirlenmesi gereken kitleler; en konservatif tedavi seçimi yapilacak bilateral kitleler; cerrahi ile ablatif tedaviler arasında seçim yapmak için cerrahi kontrendikasyonları olmayan ve ablatif tedaviler için olumlu prediktörleri olan hastalardaki kitleler biyopsi endikasyonlarını oluşturmaktaydı.

Tüm hastalarımız endikasyonlar dahilinde ilgili branşlardan tarafımıza yönlendirilen ve perkütan biyopsi yapılan hastalardan oluşmaktadır. Biyopsi öncesinde yapılan USG incelemede solid bileşeni bulumayan veya koagülopati gibi durumlar nedeniyle perkütan biyopsi yapılamayan hastalar, biyopsi yapilmadan sadece cerrahi ile tanı alan ve ayrica biyopsi sonrasi patoloji sonucu yetersiz olan veya sonucuna ulaşamadığımız hastalar çalışma dışı bırakılmıştır.

\section{Biyopsi Tekniği}

Biyopsi yapılmadan önce tüm hastalara USG ve BT veya MRG ile radyolojik görüntülemeler yapıldı ancak görüntüleme yöntemleri kesin bir tanı sağlayamadığından tedavi için yeterli değildi. Ayrıca biyopsiden önce tüm hastalarda tam kan sayımı ve pıhtılaşma testleri yapıldı. Tüm antitrombosit ajanlar veya oral antikoagülanlar işlemden önce yaklaşık 1 hafta süreyle ertelendi. Tüm hastalardan bilgilendirilmiş onam alındı. Tüm kitlelere USG eşliğinde perküktan biyopsi 12 yıllık girişimsel radyoloji deneyimi olan aynı radyolog tarafından yapıldı. Biyopsiler, çoklu örneklemeyi mümkün kılmak için, kitle lezyon sınırına kadar 17-G stilize edilmiş bir kanül yerleştirilerek içerisinde birden fazla örneklemeye olanak sağlayan yarı otomatik 18G trucut iğne ile koaksiyel bir teknikle gerçekleştirildi. Hem önceki kontrastlı çalışmalara hem de gerçek zamanlı USG doppler değerlendirmesine dayanarak kitlenin daha yüksek hücresel olduğu solid alanlar örneklenmeye çalışıldı. Biyopsi doku örneği makroskopik olarak yeterli örnek elde edilmişse, ikinci örnek alınmadı ve prosedür tamamlandı ancak doku örneği yeterli değilse ikinci veya üçüncü bir biyopsi örneği aynı giriş yerinden koaksiyel teknikle alındı. Biyopsilerden elde edilen tüm materyaller uygun solüsyonlarda patoloji tarafından analiz edildi.

\section{İstatistiksel Analiz}

Hastaların demografik özellikleri ve histopatolojik sonuçları hastane veri tabanından yeniden taranarak sonuçlar elde edildi. Üzerinde durulan özelliklerden sürekli değişkenler için tanımlayıcı istatistikler; ortalama, standart sapma, minimum ve maksimum değerler olarak ifade edilirken, kategorik değişkenler için sayı ve yüzde olarak ifade edildi. Hesaplamalar için SPSS (Version 20.0, IBM Corporation, Armonk, NY) istatistik paket programı kullanıldı.

\section{BULGULAR}

Hastalarımız yaşları 6 ile 94 arasında değişen (ortalama 59,02 $\pm 15,33$ yil) 35 erkek $(\% 61,4)$ ve 22 kadın- 
dan $(\% 38,6)$ oluşmaktaydı. 1 çocuk ve 56 erişkin hastamız mevcuttu. 29'i sol böbrek (\%50,9), 28’i sağ böbrek $(\% 49,1)$ yerleşimli olan böbrek lezyonlarının boyut ortalaması 5,6 $\pm 2,8(1,3-15) \mathrm{cm}$ idi (Tablo 1). Patoloji sonucu malign olan toplam 44 hastada (\%77,2); 41 RHK $(\% 93,2), 2$ akciğer skuamöz hücreli karsinom metastazı $(\% 4,5)$ ve 1 primeri bilinen tükrük bezinin metastaz yapan pleomorfik adenomu (\%2,3) tanisı mevcuttu. 41 RHK'un 30'u berrak hücreli RHK (\%73,2), 7'si papiller RHK (\%17,1), 3’ü kromofob RHK $(\% 7,3)$ ve 1'i sarkomatoid diferansiasyon gösteren RHK $(\% 2,4)$ idi (Tablo 2). Sonucu malign olan 28 erkek $(\% 63,6)$ ve 16 kadın $(\% 36,4)$ hastada yaş ortalaması $62,9 \pm 12,5$ (27-94) idi. 25 ’i sol böbrek $(\% 56,8), 19$ ’u sağ böbrekte $(\% 43,2)$ yer-

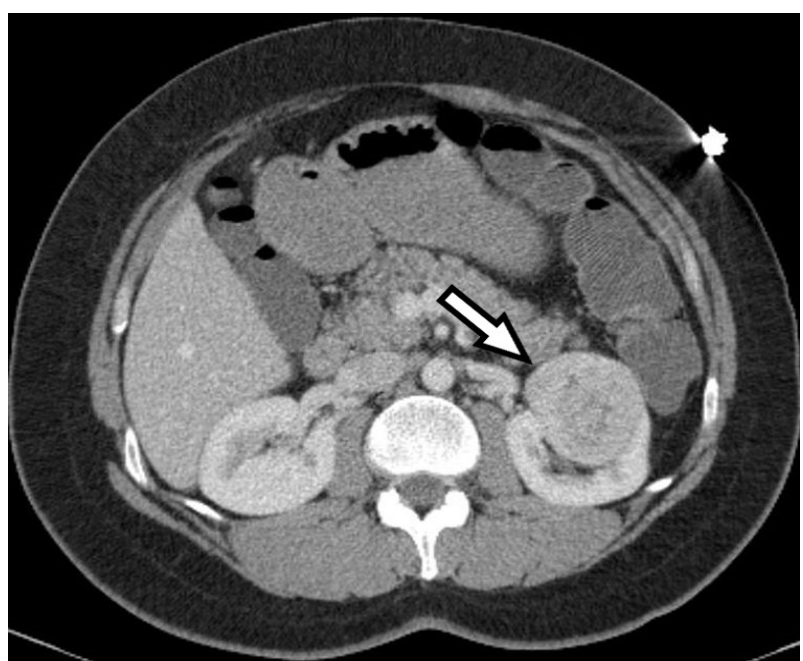

Şekil 1. Sol böbrek orta kesim lateralde egzofitik uzanımlı kontrastlı abdomen BT'de kontrast tutan hafif heterojen solid kitle lezyon izlenmektedir (ok). Lezyonun patolojik sonucu onkositom olarak raporlandi. leşim gösteren malign lezyonların boyut ortalaması 6,1 $\pm 2,9(2,4-15) \mathrm{cm}$ idi (Tablo 1). Patoloji sonucu benign olan toplam 13 hastanın $(\% 22,8)$ ise; 5’i onkositom $(\% 38,5)$ (Şekil 1), 5’i AML $(\% 38,5), 2$ 'si kronik piyelonefrit $(\% 15,4)$ ve 1'i metanefrik adenom $(\% 7,6)$ (Şekil 2) idi (Tablo 3). Sonucu benign olan 7 erkek $(\% 53,8)$ ve 6 kadın $(\% 46,2)$ hastada yaş ortalaması 45,8 $\pm 16,9$ (675)idi. 4'ü sol böbrek (\%30,8), 9'u sağ böbrekte $(\% 69,2)$ yerleşim gösteren benign lezyonların boyut ortalaması 3,9 $\pm 2,1(1,3-10) \mathrm{cm}$ idi (Tablo 1). Tüm lezyonlar içerisinde; RHK oranı $\% 71,9$, berrak hücreli RHK oranı $\% 52,6$, AML oran $1 \% 8,8$ ve onkositom oran $1 \% 8,8$ olarak bulundu.

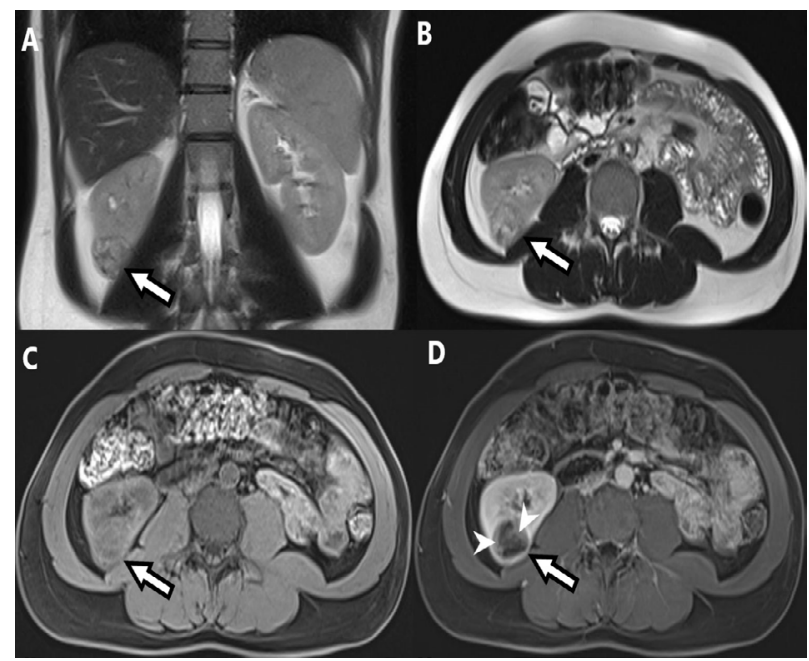

Şekil 2. Sağ böbrek posteroinferiorda hafif egzofitik uzanıml, koronal (A) - aksiyel (B) T2 ağırlıklı ve kontrastsız aksiyel T1 ağırlıklı (C) MRG'de hafif heterojen izointens sinyal özelliklerinde solid kitle lezyon izlenmektedir (oklar). Kontrastllı aksiyel T1 ağırlıklı görüntülerde (D) lezyonda kontrast tutulumu görülmektedir (ok başları). Lezyonun patolojik sonucu metanefrik adenom olarak raporland1.

Tablo 1. Hastaların demografik verileri ve patolojik özellikleri

\begin{tabular}{lccc}
\hline & Total $(\mathbf{n}=\mathbf{5 7})$ & Malign $(\mathbf{n}=\mathbf{4 4})$ & Benign $(\mathbf{n}=\mathbf{1 3})$ \\
\hline Yaş ortalaması & $59,02 \pm 15,33(6-94)$ & $62,9 \pm 12,5(27-94)$ & $45,8 \pm 16,9(6-75)$ \\
Boyut ortalaması $(\mathrm{cm})$ & $5,6 \pm 2,8(1,3-15)$ & $6,1 \pm 2.9(2,4-15)$ & $3,9 \pm 2,1(1,3-10)$ \\
\hline Cinsiyet & & & $6(\% 46,2)$ \\
\hline Kadın & $22(\% 38,6)$ & $16(\% 36,4)$ & $7(\% 53,8)$ \\
Erkek & $35(\% 61,4)$ & $28(\% 63,6)$ & $9(\% 69,2)$ \\
\hline Yerleşim & & & $4(\% 30,8)$ \\
\hline Sağ böbrek & $28(\% 49,1)$ & $25(\% 53,2)$ & \\
Sol böbrek & $29(\% 50,9)$ & $25,8)$ & \\
\hline
\end{tabular}


Tablo 2. Patoloji sonucu malign olan hastaların sinıflandırılması

\begin{tabular}{lcc}
\hline & Sayı & \% \\
\hline Berrak Hücreli RHK & 30 & 68,2 \\
Papiller RHK & 7 & 15,9 \\
Kromofob Hücreli RHK & 3 & 6,8 \\
Sarkomatoid Diferansiasyon Gösteren RHK & 1 & 2,3 \\
Akciğer Skuamöz Hücreli Karsinom Metastazı & 2 & 4,5 \\
Primeri Bilinen Tükrük Bezinin Metastaz Yapan Pleomorfik Adenomu & 1 & 2,3 \\
\hline Toplam & 44 & 100 \\
\hline
\end{tabular}

Tablo 3. Patoloji sonucu benign olan hastaların sinıflandırılması

\begin{tabular}{lcc}
\hline & Sayı & \% \\
\hline Onkositom & 5 & 38,5 \\
Anjiomyolipom & 5 & 38,5 \\
Kronik piyelonefrit & 2 & 15,4 \\
Metanefrik adenom & 1 & 7,6 \\
\hline Toplam & 13 & 100 \\
\hline
\end{tabular}

\section{TARTIŞMA}

RHK tüm kanserler içerisinde \%2-3 oranında görülür $(1,2)$. RHK’nın dünyada kanser sıralamasında erkeklerde 9, kadınlarda ise 14. sırada yer aldığı bildirilmektedir. Erkeklerde, kadınlara oranla 1,7 kat daha fazla görülür. Çalışmamızdaki malign olgularda erkek kadın oranı 1,75 olarak bulundu. RHK görülme sıklı̆ 1 açısından 6. ve 7. dekatta pik yapmaktadır ve medyan yaş 64'tür (2). Çalışmamızda tüm hastaların yaş ortalaması 59, malign hastaların yaş ortalaması 62,9 olarak elde edilmiş olup literatürle benzer özellikler taşımaktadir.

2016 Dünya Sağlık Örgütü’nün yaptığ mörlerin mevcut sinıflandırmasına göre; sitoplazma (berrak ve kromofob hücreli), yapisal (papiller), anatomik lokalizasyon (toplayıcı duktus, renal meduller) ve özgeçmiş (kazanılmış kistik hastalıkla ilişkili) gibi özellikler baz alınarak 8 tümör tipi ve birçok alt tipi tanımlanmıştır. RHK en sık görülen böbrek kanseri olup, RHK'nin en sik görülen alt tipi vakaların yaklaş1k \%80'ini oluşturan ve renal korteksten köken alan berrak hücreli karsinomdur (20). Bizim çalışmamızda tüm malign lezyonlar içerisinde RHK oranı \%93,2 ve
RHK'lar içeriside en sık berrak hücreli RHK $(\% 73,2)$ görülmüştür. RHK oranımız literatürle benzer olup berrrak hücreli RHK oranımız daha düşük bulumuştur. Görüntüleme yöntemleri ile insidental RHK görülme oranı artmıştır ve bu tümörler genelde düşük evreli tümörlerden oluşmaktadır. Histopatolojik incelemeler, kesin tanı için gereklidir ve tümör tipi, farklılaşması, nekroz ve derecelendirme, prognostik parametreler olarak kabul görmektedir (21). Bizim tüm olgularımızda tanı histopatolojik olarak konulmuştur.

Günümüzde RHK’de olduğu gibi böbreğin benign lezyonlarının sıklığında da bir artış mevcuttur. Böbreğin benign lezyonları arasında onkositom, AML, renal adenom, metanefrik adenom, piyelonefrit, böbrek kistleri ve fibroepitelyal polip gibi patolojiler oluşmaktadır (22). Böbreğin benign kitleleri malign olanlara göre daha az s1lıkla görülmektedir. Solid renal kitlenin rezeksiyonu ile yapılan büyük bir çalışma, lezyonların yaklaşı \%13'ünün benign olduğunu ve neredeyse tamamının onkositom ve anjiyomiyolipom olduğunu göstermiştir (10). Aynı oran başka çalışmalarda \%15, $\% 16,1$ ve \%17,9 olarak bulunmuştur (23-25). Bizim çalışmamızda histopatolojik olarak benign lezyon sap- 
tanma oranı \%22,8 olarak bulunmuştur. Benign lezyonlar da dahil olmak üzere renal kitlelerin gerçek insidansı net bilinmemekle birlikte, RHK insidansı, son yıllarda dünya çapında istikrarlı bir şekilde artmaktadır $(7,8)$. Cerrahi olarak tedavi edilen 4 cm'den küçük kitlelerin \% 80’i maligndir; ancak çoğu düşük dereceli, erken evre tümörlerdir ve geri kalan \% 20 benigndir (26). Böbrek kitlelerinin artan insidansı, kesitsel görüntüleme yöntemlerinin kullanımındaki artışa paraleldir (27). Biz de çalışmamızda benign lezyon saptama oranımızın literatüre göre daha yüksek saptanmasının nedeni olarak da görüntüleme teknolojisindeki gelişmeler ile beraber görüntüleme yöntemlerinin kullanım oranlarının artması olarak görüyoruz.

AML ve onkositom en sık gözlenen benign renal tümörlerdir. AML 4. ve 6. dekad arasında ve kadınlarda sık görülürken; onkositoma erkeklerde sık görülür ve yedinci dekatta pik yapar (28). Çalışmamızda AML'de ve onkositomda sirasiyla; kadın erkek oran $3 / 2,2 / 3$ ve yaş ortalamaları 46,8 ve 55,8 bulunmuş olup literatürle benzerdir. Yapılan çalışmalarda AML ve onkositomanın görülme oranları \%3-5 ve \%3-7 olarak bildirmiştir $(10,29,30)$. Bizim çalışmamızda AML ve onkositoma görülme oranları eşit ve $\% 8,8$ bulunmuştur. Bulgularımız literatüre göre AML'de daha fazla olmak üzere biraz daha yüksek oranda bulunmuştur. Buna klinik pratikte radyolojik görüntülemelerin artmasının neden olduğunu düşünüyoruz.

Kontrastsız BT'de yüksek dansitede ve T2 ağırlıklı MRG'de hipointens homojen kontrastlanan renal kitle, minimal yağ içeren AML veya papiller RHK olabilir (31). Perkütan biyopsi, cerrahi rezeksiyon dışında, onları ayırt etmenin tek yoludur. Yüksek dansitede, kontrastlanan renal kitlelerin ayırıcı tanısinda ayrıca metanefrik adenom, onkositom ve leiomyomu gibi diğer benign tümörler de bulunur (32). Çalışmamızda T2 ağırlıklı MRG'de hipointens, kontrastlı serilerde kontrast tutan ve BT'de yüksek dansiteli toplam 5 lezyonun perkütan biyopsi sonucu papiller RHK ( $n=3)$ ve yağdan fakir AML $(\mathrm{n}=2)$ olarak bildirildi.

Metanefrik adenoma nadir bir tümör olup yetişkin böbrek neoplazilerinin \%0,2'sini olusturur. Metanefrik adenomlar genelde benign karakterli olmakla beraber malign karakterde başka bir neoplaziyle beraber ol- duklarında metastaz potansiyelleri artmaktadır (33). Çalışmamızda bir olgumuz metanefrik adenom idi.

Solid renal kitlelerde, primer bir malignite olup olmadığını bilmek önemlidir. Ekstrarenal primer tümör öyküsü olduğunda soliter renal kitlelerin \% 50-85'i metastatiktir (34). Bu nedenle, bilinen bir primer malignite (akciğer kanseri, lenfoma gibi) olan bir hastada solid renal kitle tespit edilirse, olası metastaz dışında hem ikinci bir primer (RHK) hem de benign bir neoplazm düşünülmelidir. Perkütan biyopsinin bu klinik durumlarda yararlı olduğu gösterilmiştir (35). Bizim çalışmamızda da malign lezyonlar içerisinde RHK dışındaki patolojiler (\%6,8); akciğer skuamöz hücreli karsinom metastazı $(n=2)$ ve primeri bilinen tükrük bezinin metastaz yapan pleomorfik adenomu $(n=1)$ idi.

Böbrek tümörlerinin insidansındaki artış, böbrek tümörü cerrahisinin uygulanma oranlarında da artışa neden olmuştur. Böbrek tümörlerinde cerrahi, altın standart tedavi seçeneği olarak kabul görmektedir. Uzun yıllar boyunca tüm böbrek tümörlerinin cerrahi tedavisi radikal nefrektomi ile yapılmıştır (22). Ancak radyolojik gelişmelerle birlikte, küçük böbrek tümörlerinin insidansının artması ile parsiyel nefrektomi tekniğini uygulanmaya başlanmış ve bu tekniğin etkinliği ve güvenirliliği birçok çalıșmada gösterilmiștir. Ayrıca, küçük renal tümörlerde $(\leq 4 \mathrm{~cm})$ parsiyel nefrektomi altın standart yöntem olarak kabul edilmektedir (36). Son ylllarda, perkütan görüntüleme eşliğinde radyofrekans termal ablasyon (RFA), endikasyonları giderek genişleyen küçük renal kitleler için yeni bir potansiyel minimal invaziv seçenek olarak ortaya çıkmaktadır. Cerrahiye kıyasla, ablatif tedavilerin daha kolay uygulanır olması ve daha düşük komplikasyon oranlarına sahip olması; ayrıca, daha az maliyetli olması ve hastanede daha kısa kalış süresi gerektirmesi avantajlarından sayılabilir(37). Bizim olgularımızda perkütan biyopsi sonucu metastatik lezyon $(\mathrm{n}=3)$, kronik piyelonefrit $(n=2)$ ve AML $(n=5)$ dişındaki tüm kitlelere $(n=47)$ cerrahi tedavi uyguland.

Solid renal kitlelerinin tanısında perkütan biyopsilerin faydası çoğu kez güvenliği ve doğruluğu sorgulanmıştır. Ancak perkütan renal kitle biyopsisinin güvenli ve etkili olduğu gösterilmiş olup maligniteyi ve tümör tipini doğru bir şekilde tanımlama, neoplastik dokuyu 
derecelendirme yeteneği de dahil olmak üzere tanısal doğruluk oranları rutin olarak \%90'ın üzerinde bildirilmiştir $(35,38,39)$. 2000'den fazla renal kitle biyopsisinin literatür taramasının yapıldığı bir çalışmada, genel teknik başarısızlık oranı \%5, malignite için duyarlılık \%92 ve özgüllük \%90 olarak bildirilmiştir (39). Hem perkütan renal kitle biyopsisi hem de parsiyel veya radikal nefrektomi yapılan 151 küçük renal kitleyi retrospektif olarak değerlendiren bir çalışmada; malignite tanısı için, perküktan ve operasyon materyalinden elde edilen histolojiler arasında \%94 oranında uyum tespit edildi (16). Görüntüleme eşliğinde perkütan renal kitle biyopsisi, benign patolojiyi saptamak, primer böbrek kitlelerini sekonder böbrek kitlelerinden ayırmak ve gereksiz cerrahi tedavilerin sayısını azaltmak için kullanılabilen minimal morbiditeye sahip oldukça hassas bir prosedürdür.

Perkütan renal kitle biyopsisi ile ilişkili bildirilen komplikasyonlar arasında kanama ve iğneye bağlı ekilim sayılabilir. Hem psödoanevrizma hem de arteriyovenöz fistül oluşumu, perkütan böbrek biyopsisinin diğer komplikasyonlarıdır. Son zamanlarda yapılan çalışmalar perkütan biyopsiye bağlı düşük komplikasyon oranlarını göstermiştir ancak nadir de olsa $(<\% 1)$ arteriyel embolizasyon gerektirebilecek retroperitoneal kanama görülebilir $(18,19)$. İğneye bağlı ekilim, herhangi bir perkütan prosedürde potansiyel bir risktir; literatürde malign renal kitle biyopsileri ile ilişkili az sayıda parça ekilim raporu mevcuttur. Ancak, son seriler hiçbir tümör ekimi vakası bildirmemektedir. $\mathrm{Bu}$, koaksiyel teknik kullanımı gibi gelişmiş uygulamalar ile ilişkilidir (40). Koaksiyel teknik önceki literatürde önerilmiş ve biyopsi sırasında ekilimden kaçınmada özellikle etkili olduğu kanıtlanmıştır $(38,41)$. Bununla birlikte, USG veya BT kılavuzluğunda daha iyi görünürlük, daha kısa prosedür süresi ve biyopsi teknik başarısında \%15 artış gibi başka faydalar da mevcuttur (38). Bizim çalışmamızda da yapılan perküktan biyopsiler USG eşliğinde koaksiyel teknik ile yapılmış olup majör komplikasyon izlenmemiştir.

Hasta sayımızın az olması, çalışmamızın retrospektif olması, tek merkez deneyimi olması limitasyon olarak görülebilir.

\section{SONUÇ}

Sonuç olarak teknolojideki son gelişmelere rağmen renal kitlelerin ayırıcı tanısında radyolojik görüntüleme yöntemleri yeterli tanısal veri sağlamayabilir. Preoperatif malign olarak şüphelenilen renal kitleler patolojik olarak benign olabilmektedir (11). Ne yazık ki, yağdan fakir AML'leri, onkositomaları ve diğer benign renal neoplazileri RHK'dan güvenle ayırt etmek için yeterince güvenilir bulduğumuz görüntüleme özellikleri yoktur $(12,32)$. Özellikle rastlantısal olarak saptanan renal kitlenin yönetimi ile ilgili olarak biyopsinin amacı ya benign bir kitleyi malignden ayırmak ya da malign bir kitleyi doğrulamak ve onun metastatik potansiyelini değerlendirmektir. Bu nedenle özellikle malignite potansiyeli görüntüleme yöntemleri ile net değerlendirilemeyen hastalarda ve optimal tedavi seçeneklerinin belirlenmesi gereken kitlelerde (böbrek yetmezliği, soliter böbrek, yaşlı hasta vs.) preoperatif perkütan biyopsi yapılmasının faydalı olabileceğini düşünüyoruz. Nitekim yukarıda da bahsedildiği gibi son zamanlarda yapılan çalışmalarda, perkütan böbrek biyopsisinin iyi tanısal doğruluğu olan güvenli bir teknik olarak kabul edilebilmesi ve hepsinden önemlisi klinik karar verme üzerinde önemli bir etkisi olacağını göstermiştir (17-19). Ayrıca çalışmamızda böbrek kitlelerine yapilan perkütan biyosi sonucunda literatüre kıyasla benign lezyon oranlarının yüksek olması solid lezyonlarda cerrahi öncesi biyopsinin önemi açısından dikkat çekici olduğunu düşünüyoruz. Ülkemizde geleceğe dönük doğru yaklaşım geliştirebilmemize yardımcı olabilecek çok merkezli ve prospektif çalışmalara ihtiyaç olacağ 1 kanaatindeyiz.

\section{Finansal Destek}

Yazarlar bu çalıșma için mali destek almadıklarını beyan etmişlerdir.

\section{Çıkar Çatışması}

Yazarlar çıkar çatışması olmadığını beyan ederler.

\section{Etik Kurul}

$\mathrm{Bu}$ çalışma için Sağlık Bakanlığı Van Eğitim ve Araştırma Hastanesi, Klinik Araştırmalar Etik Kurulundan onay alınmıştır (Karar No:2019-02, 17 Ocak 2019). Çalışma protokolünde, Helsinki Bildirgesi etik kuralları takip edilmiştir. 


\section{Teşekkür}

Makalemiz 10. Avrasya Üroonkoloji Kongresinde (27-28 Haziran 2020) "Sözlü Bildiri” olarak kabul edilmiş ve sunulmuştur (SS-010).

\section{KAYNAKLAR}

1. Ferlay J, Colombet M, Soerjomataram I, et al. Cancer incidence and mortality patterns in Europe: Estimates for 40 countries and 25 major cancers in 2018. Eur J Cancer. 2018; 103:356-87.

2. Bray F, Ferlay J, Soerjomataram I, et al. Global cancer statistics 2018: GLOBOCAN estimates of incidence and mortality worldwide for 36 cancers in 185 countries. CA Cancer J Clin. 2018; 68(6):394-424.

3. Novara G, Ficarra V, Antonelli A, et al. Validation of the 2009 TNM version in a large multi-institutional cohort of patients treated for renal cell carcinoma: are further improvements needed? Eur Urol. 2010; 58(4):588-595.

4. Patard J-J, Leray E, Rodriguez A, et al. Correlation between Symptom Graduation, Tumor Characteristics and Survival in Renal Cell Carcinoma. Eur Urol. 2003; 44:226-232.

5. O'Connor SD, Pickhardt PJ, Kim DH, et al. Incidental finding of renal masses at unenhanced CT: prevalence and analysis of features for guiding management. AJR Am J Roentgenol. 2011; 197(1):139-45.

6. Cho E, Adami H-O, Lindblad P. Epidemiology of renal cell cancer. HematolOncolClin North Am. 2011;25(4):651-665.

7. King SC, Pollack LA, Li J, et al. Continued increase in incidence of renal cell carcinoma, especially in young patients and high grade disease: United States 2001 to 2010. J Urol. 2014; 191(6):1665-1670.

8. Hollingsworth JM, Miller DC, Daignault S, et al. Rising incidence of small renal masses: a need to reassess treatment effect. J Natl Cancer Inst. 2006; 98(18):1331-1334.

9. Cancer Stat Facts: Kidney and Renal Pelvis Cancer: National Cancer Institute [online]. 2018. Available from: http:// seer.cancer.gov/statfacts/html/kidrp.html.

10. Frank I, Blute ML, Cheville JC, et al. Solid renal tumors: an analysis of pathological features related to tumor size. J Urol 2003; 170:2217-2220.

11. Kim JH, Sun HY, Hwang J, et al. Diagnostic accuracy of contrast-enhanced computed tomography and contrast-enhanced magnetic resonance imaging of small renal masses in real practice: sensitivity and specificity according to subjective radiologic interpretation. World J Surg Oncol. 2016; 14(1):260.

12. Rosenkrantz AB, Hindman N, Fitzgerald EF, et al. MRI features of renal oncocytoma and chromophobe renal cell carcinoma. AJR Am J Roentgenol. 2010; 195(6):421-427.

13. Hindman N, Ngo L, Genega EM, et al. Angiomyolipoma with minimal fat: can it be differentiated from clear cell renal cell carcinoma by using standard MR techniques? Radiology. 2012; 265:468-477.

14. Patard JJ, Leray E, Rioux-Leclercq N, et al. Prognostic value of histologic subtypes in renal cell carcinoma: a multicenter experience. J Clin Oncol. 2005; 23:2763-2771.

15. Stella M, Chinello C, Cazzaniga A, et al. Histology-guided proteomic analysis to investigate the molecular profiles of clear cell Renal Cell Carcinoma grades. J Proteomics 2019; 191:38-47.

16. Halverson SJ, Kunju LP, Bhalla R, et al. Accuracy of determining small renal mass management with risk stratified biopsies: confirmation by final pathology. J Urol. 2013; 189(2):441-6.

17. Yang CS, Choi E, Idrees MT, et al. Percutaneous biopsy of the renal mass: FNA or core needle biopsy? Cancer Cytopathol 2017; 125:407-415.

18. Wang X, Lv Y, Xu Z, et al. Accuracy and safety of ultrasound-guided percutaneous needle core biopsy of renal masses: A single center experience in China. Medicine (Baltimore). 2018; 97(13):0178.

19. Herrera-Caceres JO, Finelli A, Jewett MAS. Renal tumor biopsy: indicators, technique, safety, accuracy results, and impact on treatment decision management. World J Urol. 2019; 37(3):437-443.

20. Moch H, Cubilla AL, Humphrey PA, et al. The 2016 WHO Classification of Tumours of the Urinary System and Male Genital Organs-Part A: Renal, Penile, and Testicular Tumours. Eur Urol. 2016; 70(1):93-105.

21. Kato M, Suzuki T, Suzuki Y, et al. Natural history of small renal cell carcinoma: evaluation of growth rate, histological grade, cell proliferation and apoptosis. J Urol. 2004; 172(3):863-866.

22. Sahin M, Canda AE, Mungan MU, et al. Benign lesions underwent radical nephrectomy for renal cancer. Turk J Urol. 2004; 30:405-409. 
23. Skolarus TA, Serrano MF, Grubb RL, 3rd, et al. Effect of reclassification on the incidence of benign and malignant renal tumors. J Urol. 2010; 183(2):455-458.

24. Kutikov A, Fossett LK, Ramchandani P, et al. Incidence of benign pathologic findings at partial nephrectomy for solitary renal mass presumed to be renal cell carcinoma on preoperative imaging. Urology. 2006; 68(4):737-740.

25. Lee SH, Park SU, Rha KH, et al. Trends in the incidence of benign pathological lesions at partial nephrectomy for presumed renal cell carcinoma in renal masses on preoperative computed tomography imaging: a single institute experience with 290 consecutive patients. Int J Urol . 2010; 17:512-516.

26. Bhindi B, Lohse CM, Mason RJ, et al. Are We Using the Best Tumor Size Cut-points for Renal Cell Carcinoma Staging? Urology. 2017; 109:121-126.

27. Welch HG, Skinner JS, Schroeck FR, et al. Regional Variation of Computed Tomographic Imaging in the United States and the Risk of Nephrectomy. JAMA Intern Med. 2018; 178(2):221-227.

28. Tamboli P, Ro JY, Amin MB, et al. Benign tumors and tumor-like lesions of the adult kidney. Part II: Benign mesenchymal and mixed neoplasms, and tumor-like lesions. Adv Anat Pathol. 2000; 7(1):47-66.

29. Mei M, Rosen LE, Reddy V, et al. Concurrent angiomyolipomas and renal cell neoplasms in patients without tuberous sclerosis: A retrospective study. Int J Surg Pathol. 2015; 23(4):265-270.

30. Choudhary S, Rajesh A, Mayer NJ, et al. Renal oncocytoma: CT features cannot reliably distinguish oncocytoma from other renal neoplasms. Clin Radiol. 2009; 64(5):517-522.

31. Hosokawa Y, Kinouchi T, Sawai Y, et al. Renal angiomyolipoma with minimal fat. Int J Clin Oncol. 2002; 7(2):120-123.
32. Silverman SG, Israel GM, Herts BR, et al. Management of the incidental renal mass. Radiology. 2008; 249(1):16-31.

33. Gözükara KH, Rifaioğlu MM. Benign Böbrek Tümörleri. In: Yıldırım A, editor. Böbrek Kanseri Güncelleme. Istanbul: Türk Üroloji Dernegi; 2016. p. 85-86.

34. Mitnick JS, Bosniak MA, Rothberg M, et al. Metastatic neoplasm to the kidney studied by computed tomography and sonography. J Comput Assist Tomogr. 1985 ;9(1):43-9.

35. Rybicki FJ, Shu KM, Cibas ES, et al. Percutaneous biopsy of renal masses: sensitivity and negative predictive value stratified by clinical setting and size of masses. AJR Am J Roentgenol. 2003; 180(5):1281-1287.

36. Bex A, Albiges L, Ljungberg B, et al. Updated European Association of Urology guidelines regarding adjuvant therapy for renal cell carcinoma. Eur Urol. 2017; 71(5):719-722.

37. Veltri A, Grosso M, Castagneri F, et al. Radiofrequency thermal ablation of small tumors in transplanted kidneys: an evolving nephron-sparing option. J Vasc Interv Radiol. 2009; 20(5):674-679.

38. Volpe A, Mattar K, Finelli A, et al. Contemporary results of percutaneous biopsy of 100 small renal masses: a single center experience. J Urol. 2008; 180(6):2333-2337.

39. Lane BR, Samplaski MK, Herts BR, et al. Renal mass biopsy--a renaissance? J Urol. 2008; 179(1):20-27.

40. Caoili EM, Davenport MS. Role of percutaneous needle biopsy for renal masses. Semin Intervent Radiol. 2014; 31(1):20-26.

41. Appelbaum AH, Kamba TT, Cohen AS, et al. Effectiveness and safety of image-directed biopsies: coaxial technique versus conventional fine-needle aspiration. South Med J. $2002 ; 95(2): 212-7$. 